\title{
Development of Projo Bale Model Based on Android Application in History and Local Wisdom Studies of Malang
}

\author{
https://doi.org/10.3991/ijet.v15i07.13219 \\ Joko Sayono ${ }^{\bowtie}$, Najib Jauhari, Lutfiah Ayundasari, Wahyu Djoko Sulistyo \\ Universitas Negeri Malang, Malang, Indonesia \\ joko.sayono.fiseum.ac.id
}

\begin{abstract}
Lack of research development on history and local wisdom studies of Malang and its integration in learning acitivities is the background of the development of Projo Bale model. Local history is full of relevant local wisdom values to be implanted in learners. The history department as the institution that produce history teachers should teach students with knowledge about local history at least the area of Malang. This Model was compiled in response to the problem. The collaboration between Outdoor Learning and Project Based Learning models with Android app based is a creative effort to leverage technology in historical learning innovations. The stages in this development include 5 phases ranging from analysis, development, design, implementation and evaluation. In the final stage of the evaluation of the model post implementation reached an average figure of $82.75 \%$ indicating this model is viable and effective as an innovative model in the study of history.
\end{abstract}

Keywords-Projo Bale Model, android app, local history of Malang.

\section{Introduction}

Local historical studies have an important position for students to conduct awareness of history, empathy, emotional proximity, national identity, and to explore the potential of the region [1]-[4]. Chance to teach local history materials wide open with the enactment of 2013 curriculum in high school. The curriculum is divided into two historical teachings, namely compulsory and interest, through the study of the history of these interests, teachers can integrate local history materials in history learning. In order to fulfill this competence History Department as an institution that produces bachelor of History education should design courses of history and local wisdom to equip prospective teachers to be able to understand and analyze various historical events at a local level that has not been addressed in national history and framing in local wisdom and can apply in learning according to the development of science and technology.

The development of learning innovation in history and local wisdom course is using Malang Raya as the focus of the study. During this time, the object and the study of 
local history especially for local area of Malang, has been special attention for historians and academics from Social Science Faculty in Universitas Negeri Malang who make it as a learning materials [5], [6]. However, during this time, the study of local history in Malang Raya is still partial, not well-rounded considering the activities of lectures are more dominant in the classroom. Outdoor class only as a support activity and provision of tasks that have not been properly installed. This became a kind of issue in historical Learning [7]. The learning model for local history courses still puts lecturers as a learning center that is fully in the role of delivering information to students is very dominant. This makes it a lack of student experience in reviewing the field directly, making the decision and drafting the results of the project.

Based on the problems, we will develop a learning system (model) which emphasizes on student activities actively and independently supported by the relevant technology [8]-[10] and utilize on local potential [11]. This model developed is a blend of two existing models namely outdoor learning and project based learning. For history students outdoor learning activities will train them skilled in finding sources of history, doing source criticism and interpreting the data [12] [14]. This is in line with the research of Çengelci [15] stating that studying outside the classroom can improve students ' ability to interpret society, nature, and the world through direct experience and training them to be active democratic community members. Basically outdoor learning activities have been implemented in the Department of History in the form of $\mathrm{KKL}$, but it is not well-established and compliment lecture in the class. In fact, according to [16] if field activities or outdoor learning is well understood, planned adequately, well taught and followed up effectively then will give opportunities for learners to develop their knowledge and skills. Therefore it is important to design outdoor learning activities in a better structured.

In addition, history students not only familiar with outdoor learning activities, are but also Project based learning (PjBL) activities, such as the development of teaching materials in small groups. The principe of $\mathrm{PjBL}$ is a student as the center of learning which is they were given a project to be completed through learning activities that lead to self-reliance [17] [18]. A learning model that emphasizes the ability of the students in implementing the project in accordance with 21 st century skills [19], [20]. While the form of project given to students is a complementary task at the end of the lecture is not a system activity that becomes the main activity of the lecture.

Therefore, to improve the quality of lectures in the history department, especially in history and local wisdom, designed a learning model that is structured by utilizing technology. This innovation of collaborative learning was developed under the title Projo Bale Model Based on Android Application in History and Local Wisdom Studies of Malang.

\section{$2 \quad$ Method}

In this research the development methods that used is ADDIE. The Model ADDIE stands for Analysis, Design, Development or Production, Implementation or Delivery, and Evaluations developed by Dick and Carry (1996). The activities in each stage ss in 
the following explanation; the analysis stage is done to know the problem and level of needs of this model; the design stage to compose a model that is ready to be validated; the development stage consist of validated activities by experts and repaired; the implementation stage is the stage of the test model and evaluation model to be the final product. This learning innovation product development uses ADDIE's development pattern with adjustments to the creation of this product detailed in the design as follows in table 1.

Table 1. Stages of Model development

\begin{tabular}{|c|c|c|}
\hline Stages & Activities & Result \\
\hline Analysis & Collecting local historical sources both field and library studies & $\begin{array}{l}\text { Data of local history } \\
\text { sources }\end{array}$ \\
\hline Desain & $\begin{array}{l}\text { Modification of Hi-Story App that contain of local history } \\
\text { information of Malang } \\
\text { Compose integrated syntax from Outdoor learning and Project } \\
\text { Based Learning activities } \\
\text { Collaborated both of model in Hi-Story App }\end{array}$ & $\begin{array}{l}\text { Hi-Story App } \\
\text { Integrated Syntax from } \\
\text { Outdoor learning and } \\
\text { Project Based } \\
\text { Learning activities }\end{array}$ \\
\hline Development & $\begin{array}{l}\text { Projo Bale's Model design is validated to material experts, } \\
\text { information technology experts, and learning model experts } \\
\text { Perform analysis of the input from the validator }\end{array}$ & $\begin{array}{l}\text { Validation results and } \\
\text { input from the } \\
\text { validator } \\
\text { Revised Model Design }\end{array}$ \\
\hline Implementasi & $\begin{array}{l}\text { Model tested on the student field } \\
\text { Students provide evaluation of model implementation }\end{array}$ & Product Test Results \\
\hline Evaluation & $\begin{array}{l}\text { Student evaluation results are recapitulated and will be analyze } \\
\text { Performed repairs }\end{array}$ & Final product \\
\hline
\end{tabular}

\section{Result and Discussion}

\subsection{Preliminary draft model}

The product of this learning innovation is a model that contains activities that become a reference for lecturers and students in the implementation of history and local wisdom. The model of this product named "Projo Bale Model based on Hi-Story application" is a blend of Outdoor Learning and Project Based Learning models and supported by Hi-Story application. The components of this Projo Bale model are;

1. Lecture activities emphasized on the orientation of students to study independently with field activities in the form of outdoor learning activities to local sites in Malang Raya. This activity will provide direct experience to students independently and structured in local historical study objects. Field activities are oriented to research (project-based) with guidance from the Hi-Story app. In this model of lectures can be done independently by students, the role of lecturers is very minimal, only as a facilitator and motivator. The lecturer serves as a briefing at the beginning of the lecture, consultant during the research and evaluator with the students at the end of the lecture. So in this model is the collaboration of learning syntax in outdoor learning $(\mathrm{OL})$ and project-based Learning $(\mathrm{PjBL})$. 
2. Hi-Story app contains information about local historical objects located in Malang Raya. The app is later installed on Android of each student who takes local history courses as their guideline for outdoor based learning project activities. The information presented in this application is the complete location of the site with directions to the location along with the ordinate point, history and development at this time and is supported with photographs of the object documentation or local historical sites.

\subsection{Learning steps in projo bale}

Systematic and planned learning is the benchmark in seeing the success of the learning process. In learning model is always known whose name syntax as a guide to the learning steps to be passed. Projo Bale model is classified into three steps of learning which in it integrates collaborative learning steps between outdoor based learning and project based learning. The steps are divided into three general steps: planning, implementation, and follow-up (Fig 1).

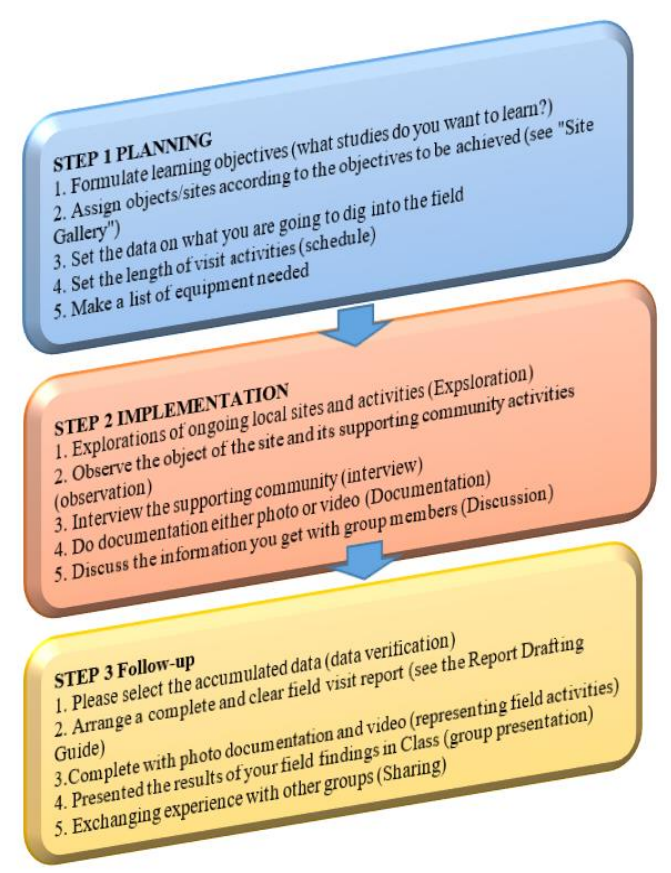

Fig. 1. Learning step in Projo Bale Model

\subsection{Site gallery in projo bale}

The site gallery in the application Model Projo Bale is a history and culture that is found in Malang Raya. In types of two categories, namely tangible, which is something that appears to be the shape of the building and intangible such as the tradition that is 
still preserved. The selection of the contents of this historical site gallery based on the effectiveness for the enacation of Projo Bale model developed that is relevant to be used as a vehicle activities outside the classroom and made a theme of learning projects.

Table 2. Historical and Cultural Sites in Malang

\begin{tabular}{|l|l|}
\hline \multicolumn{1}{|c|}{ Tangible } & \multicolumn{1}{c|}{ Intangible } \\
\hline Badut Temple & Topeng Malangan Dance \\
\hline Singosari Temple & Petik Laut \\
\hline Jago Temple & Jalani Puja Ceremony \\
\hline Kidal Temple & Entas-entas Ceremony \\
\hline Gunung Arjuno Sites & Kasada Ceremony \\
\hline Gunung Kawi Tomb & Bantengan Dance \\
\hline Mbah Wastu Tomb & Walikan Language \\
\hline Arjuno Slope Site & Labuhan Gunung Kombang Tradition \\
\hline
\end{tabular}

\subsection{The results of model application validation results}

Based on the assessment given by the model learning expert on Projo Bale model application resulted in an average achievement of $78 \%$ (Fig 2). These results are derived from three aspects of assessment that include, usage, content and views. For aspects of the assessment against the use or operation of the model that is packaged in the application reaches the number $77 \%$, the input given by the validator for this aspect is an operational system made more practical by adding instructions More detailed use. The fixes and revisions were done by changing the menu feeds and adding usage instructions to Projo Bale model application.

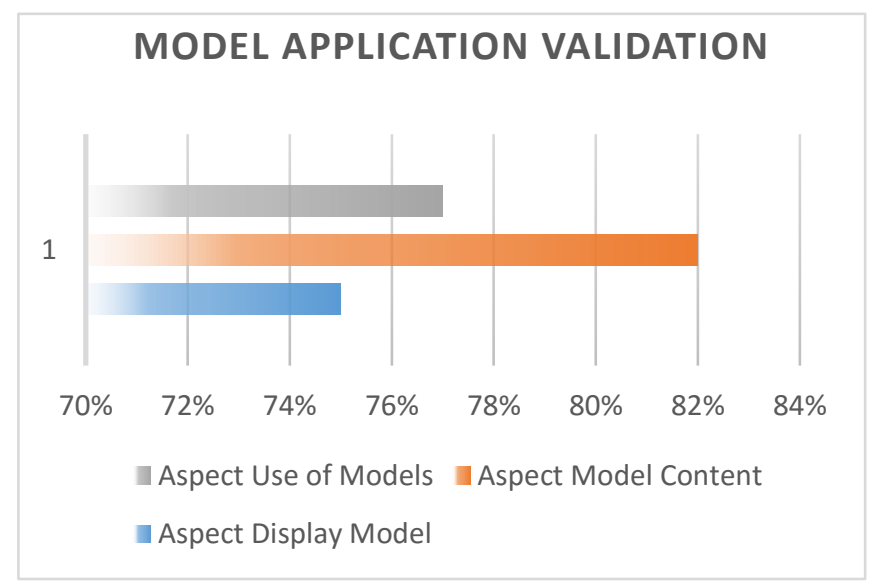

Fig. 2. The result of Validation

The images are the end result of revision of input from the validator is to add the instruction menu of application usage in more detail and detail from opening application to evaluation stage of learning activity in model. In the instructions for using 
the application model consists of nine steps of use according to the existing menu offerings. Each menu consist of description.

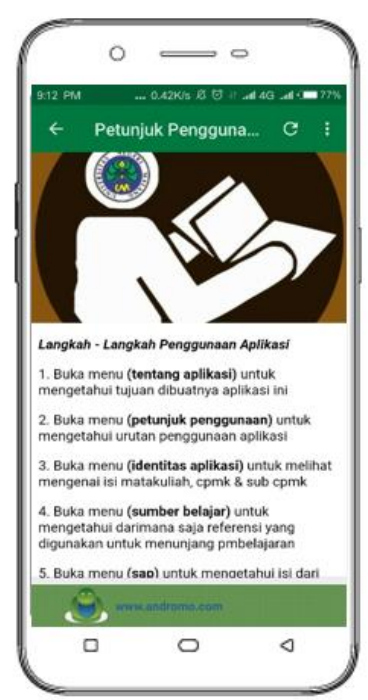

Fig. 3. Instruction Display

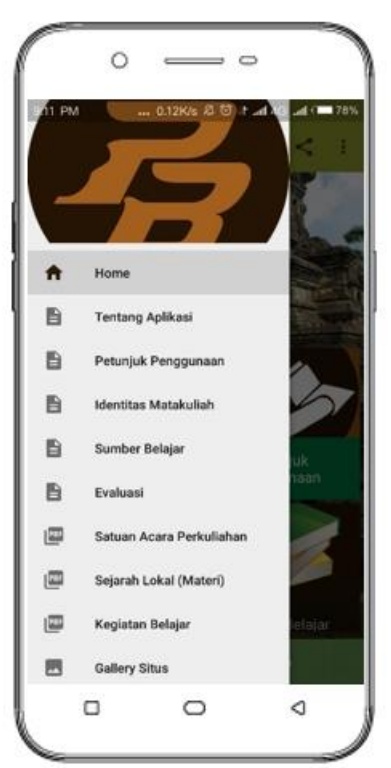

Fig. 4. Menu Display

The image is a front menu that is displayed in a list menu that becomes part of the application model presented in detail and complete according to the expert advice of 
learning model. Based on the expert advice the benefit of the front menu with list form provides an alternative for users who are accustomed to the form of a list of offerings so as to facilitate the search Content menu on the model.

Those picture is an additional form of picture 2, front menu in form of bar. Based on the input from the validator, it is also presented in the form of a list of cover images with a symbol representative of the contents of the menu, making it easier to operate. This is an alternative for users who are accustomed to menu serving other than list. So with the home page as in the user image just scroll the screen upwards then all the dishes will be displayed.

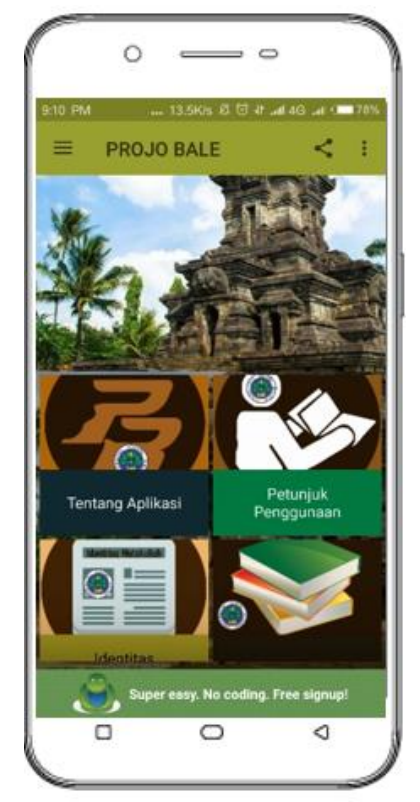

Fig. 5. General Display of Application

The second aspect of the assessment given by the validator is to be based on the content of the model application. For this aspect, the achievement value that reached the highest number compared with other aspects of $82 \%$. It can be interpreted if the content contained in the model application is good and meets the criteria that it should. The third aspect is related to the appearance of model Projo Bale application. In this aspect the assessment reached the number $77 \%$. There are some inputs given by the validator against its appearance. The first is related to the display of site offerings and introductory material display. So it is made improvements with the results as below: 


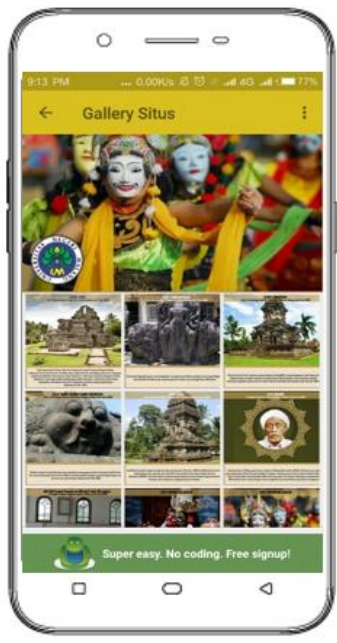

Fig. 6. Gallery Site Display

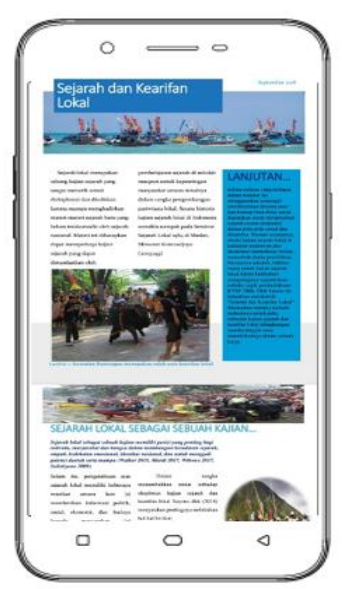

Fig. 7. Gallery Site Display

Picture is a result of revision of display on the site Galleri. There is a change here from the validator input which initially forms down the list in the tool bar with a face image of one of the site photos that is representative of the object being examined. So that with this look it becomes more interesting and easier in search or exploration of the site. The operation of this menu by pressing the screen right on the cover image at the point of the desired site, then it will be out of basic information about the local history site. It also added the institution's logo as an identity that oversees the model's development team.

The picture in addition is a revision to the content of the introductory material regarding local wisdom and history. The Validator gives suggestions for the material display is not rigid, more flexible with an attractive and contemporary look. Therefore 
the revision process is done by linking each page of the material by combining the colors and supporting images so that the material encourages the user to learn. Color adjustments to the basic material design is adapted to the information that you want to convey, such as the blue color for the local history for ocean discussion, and so on

\subsection{Model trial results}

The trials were conducted against two groups of students offering D 2016 majors in the history of FIS UM. Group members is select with random sampling method that each group consist of 6 students. Both groups apply the learning process in Projo Bale model that install on Android respectively. According to the syntax of the study, their activities are divided into three steps, namely planning, implementation and follow-up. In the second planning the group compiled an agenda of activities with a guideline on the application model Projo Bale. In this planning of each group to formulate an outdoor learning agenda in Puppet gallery in Poncokusumo District Malang, and the second group to Mbah Wastu tomb in Batu district. The Project Based Learning that they set up in learning is the same as compiling a report on field exploration and compiling site videos. In this planning activities also arranged for the agenda schedule of activities carried out, jobdesk each member of the group and property as well as various equipment needed when in the field prepared well by each group.

Second stage is implementation. At this stage occurs in the object of learning activities that have been planned before. For the first group at Sanggar Topeng Malangan, they did a learning activity along with the workshops. The activities they observe and document relate to what activities or activities take place inside the workshop, from making masks to dancing exercises or playing Topeng Malangan. The last activity did the gathering and in-depth interviews with the management of the workshop. For the group that goes to the tomb site of Mbah Wastu, the first activity performs observations and documentation of the site. Observations carried out on pilgrims visiting the tomb. Furthermore, a good interview to the pilgrims about his pilgrimage motives and the management of the tomb organizer about the history of development and existence of the site of the tomb.

In the final stage of Projo Bale model is a follow-up of the field activities. The first of each group discusses their field findings and write a report of activities both written and video-shaped. The report was later used for discussion materials in the joint sharing process between groups in the classroom. This final activity takes place in the classroom, the two groups that have been the Projo Bale model presented the results of their field activities. This activity is an event for them to demonstrate their work projects and share information. After the completion of the activity, the evaluation of the model, in the form of poll distribution that contains indicators-assessment of the effectiveness of technical model implementation. The results of the assessment instrument after the recapitulation resulted in the following achievements: 


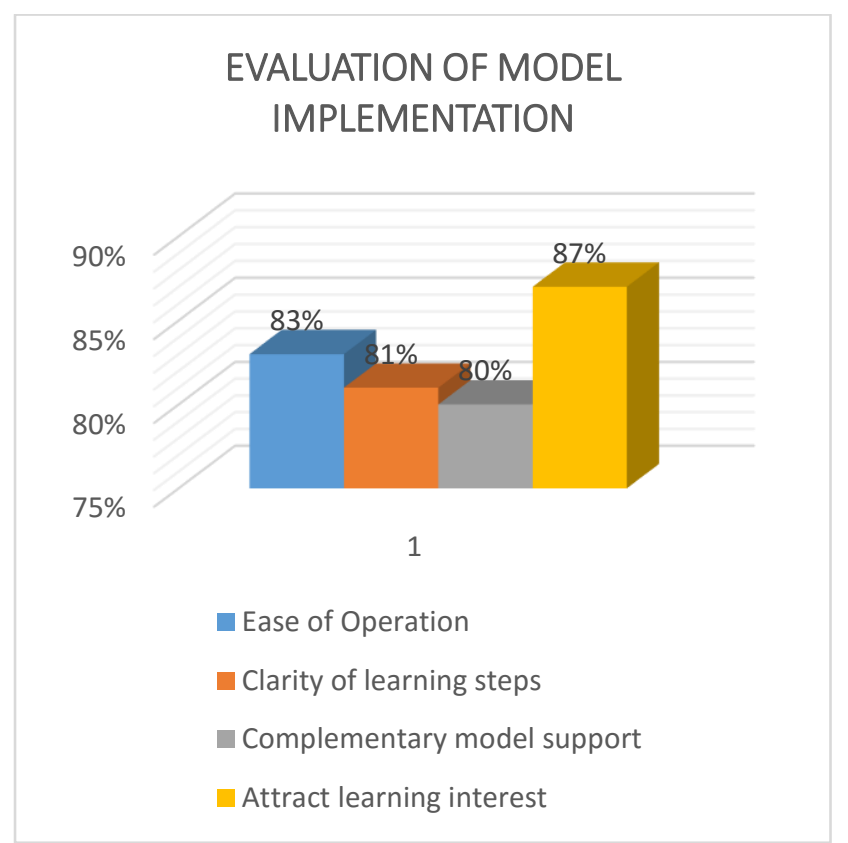

Fig. 8. Projo Bale Model Implementation Test Results

From the evaluation toward four component which is outlined in the indicators of the evaluation instrument is obtained the average model of the Projo Bale models as an effective historical learning model for students reached $82.75 \%$ which means very Good. For the first assessment component of ease of operation the student model provides assessment to reach the number $83 \%$, it means this model is very easy to operate considering the packaging in the form of applications to installed in their Android so practical to do. The second component of the clarity of the learning assessment step reached $81 \%$ which means the learning steps or syntax in Projo Bale model is very clear and can be performed every well. The third component in the completeness of the model support achieved the assessment at $80 \%$, which means supporting the complete model, this complementary assessment reached the threshold between complete and very complete considering the picture and supporting materials as the completeness aspect is limited due to the capacity of application. The last component relates to the role of the Projo Bale model to attract students ' learning interest. Here reached the highest scoring figure of up to $87 \%$ which means very well. This is because this model is in accordance with their pattern of learning, their freedom in field exploration of historical sites that are well presented and which are a tradition to spur their sense of ignorance. The outdoor learning activities integrated in this model become one of the fun learning activities with a new atmosphere, which is the direct experience of the field [21], [22]. Project based learning that they applied by arranging a video about the site can provide an interesting experience and suitable with their learning style [18], [20], [23], [24]. Thus the assessment on this component is high and 
it becomes a conclusion that the model Projo Bale based on the Hi-Story application is feasible and effective as a model of historical learning.

\section{Conclusion}

Development learning innovation model based on Android application through 5 stages in research and model development procedures.

Firstly, is an analysis that includes consideration to be a strong background for the development of the model. The most basic consideration is about the importance of local history studies as a provision of knowledge for learners.

Secondly, is the drafting design or draft model that is the prototype of Projo Bale model application with the use of Android technology.

Thirdly, is the development process (Development) at this stage carried out validation activities by the model experts to assess the effective elements of the model developed. The assessment result of the validator has been $78 \%$, so it is generally declared feasible. There are several records given by the validator either to the model's contents content, the view to the usage procedure. Suggest from this validator that is the basis for developers to revise the product to be ready for testing. At the test stage, it is applied to two sample groups with different learning destination objects. Based on the trial results it can be seen that the model can be properly applied to any of its syntaxes. Until the final evaluation process of this test has received agility assessment that reaches a figure of $82.75 \%$ whose model is worthy and effective as a model of historical learning that can build a good learning climate and means of understanding of local historical material.

\section{$5 \quad$ References}

[1] N. Asriati, "Mengembangkan Karakter Peserta Didik Berbasis Kearifan Lokal Melalui Pembelajaran di Sekolah," Jurnal Pendidikan Sosiologi dan Humaniora, vol. 3, no. 2, 2012.

[2] L. Ayundasari, "Urgensi Pembelajaran Sejarah Berbasis Potensi Lokal Bahari untuk Menumbuhkan Minat Wirausaha di Pesisir Selatan Kabupaten Malang," Sejarah dan Budaya: Jurnal Sejarah, Budaya, dan Pengajarannya, vol. 11, no. 2, pp. 211-219, 2017. https://doi.org/10.17977/um020v11i22017p211

[3] A. M. Santoso, "Konsep diri melalui pendidikan berbasis keunggulan lokal sebagai model pendidikan berkarakter dan berbudaya bangsa di era global," in Proceedings of The 4th International Conference on Teacher Education, 2010, pp. 477-486.

[4] R. Yunus, "Transformasi nilai-nilai budaya lokal sebagai upaya pembangunan karakter bangsa," Jurnal Penelitian Pendidikan, vol. 13, no. 1, pp. 67-79, 2013.

[5] D. Budiyono, E. E. Nurlaelih, and R. Djoko, "Lanskap Kota Malang Sebagai Obyek Wisata Sejarah Kolonial,” Jurnal Lanskap Indonesia, vol. 4, no. 1, 2012.

[6] Joko Sayono, L. Ayundasari, W. D. Sulistyo, and R. Ridho'i, Situs Sejarah Malang Raya Masa Islam dan Kolonial. Malang: Jurusan Sejarah FIS UM, 2019

[7] S. H. Hasan, "Problematika Pendidikan Sejarah," Bandung: FPIPS UPI, 2003.

[8] H. Rasku-Puttonen, A. Eteläpelto, P. Häkkinen, and M. Arvaja, "Teachers' instructional scaffolding in an innovative information and communication technology-based history 
learning environment," Teacher Development, vol. 6, no. 2, pp. 269-287, 2002. https://doi.org/10.1080/13664530200200168

[9] J. W. Saye and T. Brush, "Scaffolding critical reasoning about history and social issues in multimedia-supported learning environments," Educational Technology Research and Development, vol. 50, no. 3, pp. 77-96, 2002. https://doi.org/10.1007/BF02505026

[10] B. Kurniawan, I. Idris, A. Purnomo, A. Wiradimadja, and S. Sukamto, "Using Broadcasting Learning Design to Enhance Student's Experiential Skill,” Int. J. Emerg. Technol. Learn., vol. 14, no. 16, pp. 172-180, Aug. 2019. https://doi.org/10.3991/ijet.v14i16.10652

[11] W. D. Sulistyo, U. Nafi'ah, and I. Idris, "The Development of E-PAS Based on Massive Open Online Courses (MOOC) on Local History Materials,” Int. J. Emerg. Technol. Learn., vol. 14, no. 09, p. 119, May 2019. https://doi.org/10.3991/ijet.v14i09.10143

[12] H. Bilton, Outdoor learning in the early years: Management and innovation. Routledge, 2010. https://doi.org/10.4324/9780203860137

[13] J. E. Dyment, "Green school grounds as sites for outdoor learning: Barriers and opportunities," International Research in Geographical \& Environmental Education, vol. 14, no. 1, pp. 28-45, 2005. https://doi.org/10.1080/09500790508668328

[14] J. Sayono, L. Ayundasari, W. D. Sulistyo, and R. Ridhoi, "Utilization of Syphon Metro Kepanjen as Outdoor Learning Site for History Students," in 1st International Conference on Social Knowledge Sciences and Education (ICSKSE 2018), 2019. https://doi.org/10.2991/icskse-18.2019.14

[15] T. Çengelci, "Social Studies Teachers' Views on Learning Outside the Classroom.," Educational Sciences: Theory and Practice, vol. 13, no. 3, pp. 1836-1841, 2013.

[16] J. Dillon et al., "The value of outdoor learning: evidence from research in the UK and elsewhere," School science review, vol. 87, no. 320, p. 107, 2006.

[17] B. J. Barron et al., "Doing with understanding: Lessons from research on problem-and project-based learning," Journal of the learning sciences, vol. 7, no. 3-4, pp. 271-311, 1998.

[18] R. J. DeFillippi, Introduction: Project-based learning, reflective practices and learning. Sage Publications Sage CA: Thousand Oaks, CA, 2001. https://doi.org/10.1177/1350507601 $\underline{321001}$

[19] S. Bell, "Project-based learning for the 21st century: Skills for the future," The Clearing House, vol. 83, no. 2, pp. 39-43, 2010. https://doi.org/10.1080/00098650903505415

[20] P. C. Blumenfeld, E. Soloway, R. W. Marx, J. S. Krajcik, M. Guzdial, and A. Palincsar, "Motivating project-based learning: Sustaining the doing, supporting the learning," Educational psychologist, vol. 26, no. 3-4, pp. 369-398, 1991. https://doi.org/10.1080/ $\underline{00461520.1991 .9653139}$

[21] Y. Bamberger and T. Tal, "Learning in a personal context: Levels of choice in a free choice learning environment in science and natural history museums," Science Education, vol. 91, no. 1, pp. 75-95, 2007. https://doi.org/10.1002/sce.20174

[22] Y. Takeuchi and M. Sugimoto, "CityVoyager: an outdoor recommendation system based on user location history," in International Conference on Ubiquitous Intelligence and Computing, 2006, pp. 625-636. https://doi.org/10.1007/11833529 64

[23] S. Jacques, S. Bissey, and A. Martin, "Multidisciplinary Project Based Learning Within a Collaborative Framework: A Case Study on Urban Drone Conception," International Journal of Emerging Technologies in Learning (iJET), vol. 11, no. 12, pp. 36-44, Dec. 2016. https://doi.org/10.3991/ijet.v11i12.5996

[24] J. S. Krajcik and P. C. Blumenfeld, Project-based learning. na, 2006. https://doi.org/10.1017/CBO9780511816833.020 


\section{Authors}

Joko Sayono is an Indonesian Historical Education, one of the lecturers in History Department, Faculty of Social Science, Universitas Negeri Malang. He is interested in Islamic Hystory and learning evaluation. Email: joko.sayono.fis@um.ac.id.

Najib Jauhari is an Islamic Historical Education, one of the lecturers in History Department, Faculty of Social Science, Universitas Negeri Malang.

Lutfiah Ayundasari is an Islamic Historical Education, one of the lecturers in History Department, Faculty of Social Science, Universitas Negeri Malang. He is majoring in learning evaluation.

Wahyu Djoko Sulistyo is an Indonesian Historical Education, one of the lecturers in History Department, Faculty of Social Science, Universitas Negeri Malang. He is interested in educational history and learning innovation.

Article submitted 2020-01-16. Resubmitted 2020-02-02. Final acceptance 2020-02-06. Final version published as submitted by the authors. 